\title{
CAN PRODUCT LEADERSHIP BE A PREDICTOR OF A CUSTOMER'S LOYALTY?
}

\author{
MS. Eric Santosa \\ Universitas Stikubank \\ (ericsantosa.2010@gmail.com)
}

\begin{abstract}
Leading companies commonly employ a particular strategy to cover a market. They might choose product leadership, service support excellence, customer intimacy strategy, as well as a combination of them.

The use of these strategies is obviously to gain more customers, since the product becomes a choice as an effect of the brand equity strengthening. While firms are very concerned with customer loyalty to maintain a stable sales volume, a question arises whether the brand equity has an effect on the customer's loyalty. Logically, if a strategy can develop the product's brand equity which in turn propels cutomers to buy it, it will hopefully improve customers' loyalty as well.

Therefore, this study is designed to answer the questions, (1) which strategy (among the three) adds power to the brand equity, (2) the brand equity is influential to the customer's loyalty, and (3) the product leadership can predict the customer's loyalty. Three antecedents of brand equity are employed, i.e. product leadership, service support excellence, and customer intimacy. These three variables, along with brand equity can also indicate as predictors of customer's loyalty. A sample consisting of 100 respondents withdrawn through a judgment method. Data were analyzed by Amos 5.0 and SPSS 16.0. The results denote that the relationships between product leadership and customer intimacy to brand equity, also brand equity to customer's loyalty are significant. On the contrary, the relationship of service support excellence to brand equity and the relationship of product leadership to customer's loyalty are trivial.
\end{abstract}

Keywords: product leadership, service support excellence, customer intimacy, brand equity, customer's loyalty

\section{INTRODUCTION}

It is very common that every firm strives to attain a high market share and great sales volume. It is understandable that this is not easily done. Both market share and great sales volume frequently refer to a product's competitive advantage, such as a high quality, better design than competitors, reasonable price, more value than others. In addition, the competitive product should have a higher technology than others. Consequently, the product should be of excellent quality, good price, better design and techonology than the others. Otherwise, customers will leave or ignore the product.

The competitive advantage allows that the product should have a right and superior cus- tomer value, denoting that it is distinctive, unique, which indicates that it is dissimilar to any other (Craven, 2000). The product can be distinguished from competitors. Moreover, while a product grows to be a leader, many other firms hardly attempt to imitate it. They launch new products which are nearly similar, but of a lower price. As a result, tight competition inevitably arises. In such a situation, the product's sales volume will temporarily slow down, or may even decline.

The role of the Research and Development (R\&D) department thereby becomes critical. The company (via this department) needs to open its eyes and ears, actively learn the market, and carefully predict what could happen next. Any 
new product might be a leader if it can catch the new market's desire. Therefore, by carefully preparing and thoroughly processing the information, the result is in accordance with the company's expectation that the product meets future needs. Optimistically, it will be a superior product. It will be better off if the superior position does not only consist of a single product, but multiple products. It allows for difficulties when competitors imitate and lets a product be a focal point while others are probably duplicating it. In addition a higher price is probably understandable since the product has more advantage (Thompson, et al., 2010).

A better quality and more value product, as perceived by customers, unsurprisingly strengthens the brand equity. Likewise when the company provides an excellent support service, as this contributes to the user's convenience, it unavoidably creates a strong impression on customers. The strong brand perception is also influenced by the product being close to customers demands. It is supposed that the strength of a brand equity will in turn affect the customer's loyalty.

The terms of product leadership and customer intimacy are apparently not unfamiliar since Treacy \& Wiersema (1997) had introduced them as two out of three value disciplines for firms who want to succeed in the market. The use of service support excellence in this study is inevitable, since it is in accordance with a firm's effort to strengthen the brand equity. Therefore, the study is aimed at answering questions, such as (1) which strategy adds power to the brand equity, (2) the brand equity is influential to the customer's loyalty, and (3) the product leadership can predict the customer's loyalty. The highlight of product leadership is inspired by Kalypso (http: kalypso.com, capabilities, services, product-leadership-transformation) that it is prominent in today's highly competitive marketplace.

The empirical data were withdrawn from Nokia's customers. It is assumed that at that time the study was conducted, Nokia's products has a position as market leaders (http: en.wikipedia. org, wiki, Nokia; http:gadnix.com, 2009/04/ market-share-ponsel-di-indonesia; www. imglanding? $\mathrm{q}=$ market $\% 20$ share $\% 20$ nokia\&imgu rl; www.nokia.com; http:old.forumponsel.com, forum, showflat-Number-182727-page-0-sb-5fpart-1.html. Some theoretical reviews are provided. Some illumination of their methods, analysis and findings is reported.

\section{Product Leadership and Brand Equity}

An Understanding of Product Leadership. MISC Magazine (2014) intepretes product leadership as: "Offering customers leading edge products that consistently enhance the customer's use or application of the product, thereby making its rivals' goods obsolete". Hopkin (2011a) suggests that product leadership is the ability of the product manager to lead the product team. If the product manager succeeds, the product succeeds. With leadership, ideas flow, solid products are released and sales increase. He introduces five steps to be a good leader, they are, (1) build relationships, (2) develop trust, (3) improve visibility, (4) increase value, and (5) create accountability.

Hopkin (2011b) also highlights that the product manager's role is very important. The product manager plays a key role in the success of the company. He then proposes five rules, (1) building the people on the manager's team, (2) developing trust, (3) representing the product team, (4) cultivating stability, and (5) removing roadblocks.

Kalypso sees product leadership as a new emerging strategy, leaving behind traditional operating models such as customer intimacy and operational excellence, which rely upon product superiority by delivering innovative products that meet ever-evolving customer needs (http: kalypso.com, capabilities, services, productleadership-transformation). Kalypso proposes a model named Kalypso's Product Leadership Transformation. It is an integrated process focusing on the interrelationships between the following key elements: (1) Human Capital Organization; (2) Consumer Insights \& Value Management; (3) Customer Strategic Alliances; (4) Ideation and Idea Management; (5) New Product Development Process; (6) Product Life- 
cycle Management Technology; (7) Portfolio Management; and (8) Roadmapping.

Developing New Product. Developing a new product can vary, from products that have never existed previously, or were not previously available on the market, products that are developed from earlier models (adding new features) to just modifying an old one. Booz, Allen, and Hamilton (in Kotler, 2000) suggest six types of products that can be classified as new,

a. New to the world products, new products that create an entriely new market.

b. New product lines, new products that allow a company to enter an establ;ished market for the first time.

c. Additions to existing product lines, new products that supplement a company's established product lines (package sizes, flavors, and so on).

d. Improvements and revisions of existing products, new products that provide improved performance or greater perceived value and replace existing products

e. Repositioning existing products so they target new markets or market segments.

f. Cost reductions, new products that provide similar performance at lower cost.

Factors Affecting New Products' Failure. Not all new products successfully sustain the market. Not long after their launch, some quickly disappear. Kotler (2000) proposes several factors that affect the failure, (1) a high-level executive pushes a favorite idea through despite negative market research findings, (2) the idea is good, but the market size is over estimated, (3) the product is not well designed, (4) the product is incorrectly positioned in the market, not advertised effectively, or is overpriced, (5) development costs are higher than expected, (6) competitors fight back harder than expected.

Kotler and Keller (2006) suggest that the development of new products should take several of the following factors as hindrances into account, (1) shortage of important ideas in certain areas, (2) fragmented markets, (3) social and governmental constraints, (4) cost of development, (5) capital shortages, (6) a faster required development time, (7) shorter product life style.

The Definition and Operation of the Variabel. Based on the literature mentioned, the product leadership variable can be clearly figured out as: "An approach to the market, which relies upon product superiority by delivering innovative products that meet everevolving customer needs." The variable is operated through the following indicator i.e. (1) product's variety, (2) product's competitiveness, (3) superior quality, and (4) easy operating.

An Understanding of Brand Equity. Kotler and Armstrong (2000: 357) define that: "Brand equity is a value of a brand in which the brand has high brand loyalty, brand awareness, high perceived quality, strong brand association, and other intangible assets such as patent, trademarks, and channel relationships." Along with Kevin Lane Keller, Kotler delineates brand equity in another way (Kotler \& Keller, 2006: 258):

Brand equity is the added value endowed to products and services. This value may be reflected in how consumers think, feel and act with respect to the brand, as well as the prices, market share, and profitability that the brand commands for the firm. Brand equity is an important intangible asset that has psychological and financial value to the firm.

Further, Kotler \& Keller (2006: 497) confirm that: "...marketing communication activities contribute to brand equity in many ways: by creating awareness of the brand; linking the right associations to the brand image in consumers' memory, eliciting positive brand judgments of feelings; and/or facilitating a stronger consumerbrand connection." Peter and Olson (2002: 136) describe brand equity from their viewpoint, that brand equity is,

Brand equity concerns the value of the brand to the marketer and to the consumer. From the marketers' perspective, brand equity implies greater profit, more cash flow, and greater market share. From the consumer's perspective, brand equity is reflected by the 
brand attitude based on belief about positive product attributes and favorable consequences of brand use.

Likewise, Schiffman and Kanuk (2000: 193) identify brand equity from their perspective, that brand equity is,

The term brand equity refers to the value inherent in a well-known brand name. From a consumer's perspective, brand equity is the added value bestowed on the product by the brand name. Brand equity facilitates the acceptance of new products and the allocation of preferred shelf space and enhances perceived value, perceived quality, and premium pricing options. For many companies, their most valuable assets are their brand names. Because of the escalation of new product costs and the high rate of new product failures, many companies prefer to leverage their brand equity through brand extensions, rather than risk launching a new brand.

The five definitions talked about virtually refer to the same substance. It indicates that brand equity encompasses a large understanding that can be implied in various ways. However, for the sake of the study it will be figured out without reducing the substance, that "brand equity is the added value endowed to products and services. This value may be reflected in how consumers think, feel and act with respect to the brand, reflected by the brand attitude based on belief about positive product attributes and favorable consequences of brand use."

Brand Equity Models. Kotler and Keller (2006: 260-262) suggest four models to measure brand equity. Those are Brand Asset Valuator (BAV), Aaker Model, BrandZ, and Brand Resonance. Subsequent enlightenment will be provided.

a. Brand Asset Valuator (BAV), proposes four key components, or pillars, of brand equity:

1) Differentiation, measures the degree in which a brand is seen as different from others.

2) Relevance, measures the breadth of a brand's appeal.
3) Esteem, measures how well the brand is regarded and respected.

4) Knowledge, measures how familiar and intimate consumers are with the brand.

b. AAKER Model, recommends that brand equity is a set of five categories of brand assets and liabilities linked to a brand that add to or subtract from the value provided by a product or service to a firm and/or to that firm's customers. These categories of brand assets are (1) brand loyalty, (2) brand awareness, (3) perceived quality, (4) brand associations, (5) other propietary assets such as patent, trademarks, and channel relationships.

c. BRANDZ, proposes the Brand Dynamics pyramid. Virtual brand bulding involves a sequential series of steps, where each step is contingent upon successfully accomplishing the previous step. The objectives at each step are (1) presence, (2) relevance, (3) performance, (4) advantage, and (5) bonding

d. Brand Resonance, also advocates a brand building as an ascending and sequential series of steps. Essentially it consists of (1) brand salience, which relates to how often and easily the brand is evoked under various purchase or consumption situations, (2) brand performance, relates to how the product or service meets the customer's functional needs, (3) brand imagery, deals with the extrinsic properties of the product or service, including the ways in which the brand attempts to meet customers' psychological or social needs, (4) brand judgments, focuses on the customers' own personal opinions and evaluations, (5) brand feelings, customer emotional responses and reactions with respect to the brand, (6) brand resonance, refers to the nature of the relationship that customers have with the brand and the extent to which customers feel that they are "in sync" with the brand.

The Operation of the Brand Equity Variable in Use. Referring to the model of the Brand Asset Valuator (Kotler \& Keller, 2006), the model is conveniently supposed as the one that 
can meet the purpose of the study. Therefore, in this study the brand equity is measured through differentiation, relevance, esteem and knowledge.

The Relation between Product Leadership and Brand Equity. Product leadership's aim is to produce superior products. These superior products certainly should be in accordance with the needs and desires of the market which are distinctive (Cravens, 2000). When a product has the appearance of having attributes and benefits (Peter \& Olson, 2002), it inevitably stimulates the customers' need to buy (Assael, 1995). Therefore, the superior products' attributes and benefits influence the customers' cognitive process (Peter \& Olson, 2002). While brand equity may be reflected in how consumers think, a hypothesis can be formulated as follows:

\section{H1: Product leadership influences brand equity}

\section{Support Service Excellence}

An Understanding of Service. Kotler and Keller $(2006,372)$ declares that: "Service is any act or performance that one party can offer to another that is essentially intangible and does not result in the ownership of anything. Its production may or may not be tied to a physical product." Zeithaml and Bitner (2003, 3) differentiate this within a simple term and a broad term. The simple term refers to: "Services are deeds, processes, and performances." Whereas the broad one defines service as: "Including all economic activities whose output is not a physical product or construction, is generally consumed at the time it is produced, and provides added value in forms (such as convenience, amusement, timeliness, comfort, or health) that are essentially intangible concerns for its first purchaser." Both these simple and broad terms are virtually already incorporated in Kotler \& Keller's definition. Therefore, what is meant as service, which will be in use, is: "Service is any act or performance that one party can offer to another that is essentially intangible and does not result in the ownership of anything. Its production may or may not be tied to a physical product."
Perceived Service versus Expected Service. Consumers judge a service from their own view point. Customers'perception might be established by several factors, such as advertising, word of mouth, and past experience (Schiffman \& Kanuk, 2000). When the actual service is not in accordance with customers' perceptions, the customers will inevitably be disappointed. Conversely, if the actual service fits his/her perception, he/she will purchase/use the service again. For the company, its aim is not only to deliver service as it's customers perceive, but also make customers be impressed and happy with the service he/she has experienced. However, satisfying the customers is not easy, since there are many gaps between actual and expected services (Kotler \& Keller, 2006): (1) the gap between customer expectation and management perception, (2) the gap between management perception and service quality specification, (3) the gap between service quality specification and service delivery, (4) the gap between service delivery and external communications, and (5) the gap between perceived service and expected service.

Excellent Service: A Limitation. While many important things concerning service have been talked about, it necessitates the compilation of a limitation of excellent service which will be in use. Accordingly, what an excellent service is "is a service which is delivered to customers in a particular way such that the customers feel that the service they experience is at least in accordance with their expectation."

Customer's Satisfaction. A company is supposed to have delivered an excellent service if the customers are satisfied by the service they experience. According Kotler and Keller (2006): "Satisfaction is a person's feeling of pleasure or disappointment resulting from comparing a product's perceived performance (or outcome) with his or her expectation of it." Zeithaml and Bitner (2003: 86) propose an almost similar definition, that is: "Satisfaction is the consumer's fulfillment response. It is a judgment that a product or service feature, or the product or service itself provides a pleasurable level of consumption-related fulfillment." So, principal- 
ly: "A customer finds satisfaction if the service he/she experiences matches his/her expectation, or even more."

What factors affect the satisfaction? Zeithaml and Bitner (2003) assert some factors such as, (1) product and service features, (2) customer emotions, (3) attributions for service success or failures, (4) perceptions of equity and fairness, and (5) other customers, family members and co-workers.

How Should a Company Do. An excellent service is inevitable for companies who want to keep their customers and to enlarge their market. Nevertheless, it needs a lot things that are not easy, such as the ability of employees to subtly deliver a service, sophisticated equipment, a comfortable place, good management, and so on. Kotler and Keller (2006) suggest several options in practicing service quality management, i.e. (1) applying a strategic concept to "customer obsessed' orientation, the company should have some sensibility towards its target and customers' needs, (2) top management's commitment towards service quality instead of profit, (3) employing high standards of service, 'better and faster' in reliability, resilience, and innovativeness than others, (4) operating self-service technologies (SSTs), such as Automated Teller Machines (ATMs), self pumping at gas stations, self checkout at hotels, self-ticket purchasing, and the like, (5) utilizing a monitoring system, (6) satifying customer complaints, and (7) satisfying employees as well as customers.

The Operation of the Support Service Excellence Variable in Use. The variable will be measured by the extent of the service centre network, the easiness of finding/getting to a service centre, the customer's satisfaction, the favorable response of the employees, and the information availability.

The Relation between Service Support Excellence and Brand Equity. Services can be delivered in many ways, one of six is tangible goods with accompanying services (Kotler \& Keller, 2006). The purpose of the accompanying services is obviously to support the product's image, which apparently strengthen the favorable cognitive process about the product (Peter
\& Olson, 2002). Therefore, a hypothesis can be drawn as follows,

$\mathrm{H} 2$ : Service support excellence influences brand equity

\section{Customer Intimacy}

Relationship Marketing: An Understanding. What is purported to be relationship marketing is a system of marketing that: "... has the aim of building long-term mutually satisfying relationships with key parties, customers, suppliers, distributors, in order to earn and retain their longterm preference and business". (Kotler, 2000: 13). Another definition comes from Zeithaml and Bitner (2003: 157) that relationship marketing: “ $\ldots$ is a philosophy of doing business, a strategic orientation that focuses on keeping and improving current customers rather than on acquiring new customers." Thus, principally, relationship marketing has the aim of building and keeping long-term mutually satisfying relations with customers, suppliers, and distributors.

Customer Relationship Management (CRM). Customer relationship management is: "The process of managing detailed information about individual customers and carefully managing all customer 'touch points' to maximize customer loyalty" (Kotler \& Keller, 2006: 144). The term 'touch points' is: "The process of managing detailed information about individual customers and carefully managing all customer 'touch points' to maximize customer loyalty" (Kotler \& Keller, 2006: 144).

A Framework of CRM. Peppers and Rogers (in Kotler \& Keller, 2006) outline a four step framework for one-to-one marketing that can be adapted to CRM marketing as follows, (1) identify the company's prospect and customers, (2) differentiate customers in term of their needs and their value to the company, (3) interact with individual customers to improve knowledge about their individual needs and to build a stronger relationship, (4) customize products, services, and messages to each customer.

What is a Company's Strategy to Build a Relationship? Leonard Berry and A. Parasuraman (in Zeithaml and Bitner, 2003) 
identify that a relationship can occur in a particular event. One particular event is the market that the company operates in. They (Leonard Berry and A. Parasuraman) propose a framework that suggests that relationship marketing can take place at different levels and that each successive level of strategy results in ties that bind the customer a little closer to the company. The levels are as follows, (1) financial bonds, includes volume and frequency rewards, bundling and cross selling, and stable pricing, (2) social bonds, consists of continuous relationships, personal relationships, and social bonds among the customers, (3) customization bonds, contains anticipation/innovation, mass customization, and customer intimacy, (4) structural bonds, comprises integrated information systems, joint investments, and shared processes and equipment.

Customer Intimacy Strategy. Zethaml and Bitner (2003: 177) assert that: "The strategy suggests that customer loyalty can be encouraged through an intimate knowledge of individual customers and through the development of "one-to-one" solutions that fit the individual customers' needs." This is similar to Misc (2014) who states that customer intimacy: “... requires heavy investments in customer knowledge, customer service and the ability to customize." In addition, Mars (2014) also introduces a similar idea, that customer intimacy: "...focuses on offering a unique range of customer services that allow for the personalization of service and the customization of products to meet differing customer needs." Later on, Zeithaml \& Bitner's definition will be in use.

Measuring the Customer Intimacy Variable. The customer intimacy variable is operationed by indicators as follows, the product's message is personal, customer oriented, and personalized program.

The Relation between Customer Intimacy and Brand Equity. Customer intimacy produces a unique one-to-one product design (Zeithaml \& Bitner, 2003). This unique design allows the product to be superior and distinctive (Cravens, 2000). It apparently encourages the favorable customer's cognitive process. As a result, a hypothesis can be withdrawn as follows,

H3: Customer intimacy influences brand equity

\section{Customers’ Loyalty}

An Understanding of Loyalty. Initially, the conceptualization of the loyalty construct focused on brand loyalty with respect to tangible goods (Kostecki, 1994). Cunningham (1956) defined brand loyalty as: "...the proportion of purchases of a household devoted to the brand purchased most often." The definition is still applicable since a similar statement was made by Assael (1995: 131) which is as follows: "Brand loyalty represents a favorable attitude toward a brand resulting in consistent purchase of the brand over time."

While only a few studies have examined customer loyalty to services (Oliver, 1997), in a services context, loyalty is frequently defined as observed behavior (Liljander \& Strandvik, 1995). However, Dick and Basu (1994) find that intangible attributes such as reliability and confidence may play a major role in building or maintaining loyalty. Jacoby and Chestnut (1978) suggest that not only behavioral aspects but also attitudinal aspects should be considered in the loyalty dimensions. Brand loyalty was then believed to be a biased (i.e. non random), behavioral response (i.e. purchase), expressed over time, by some decision making unit, with respect to one or more brands out of such brands, and is a function of the psychological processes. The attitudinal aspects is viewed as, for instance, the willingness to recommend a service provider to other consumers (Selnes, 1993 in Bloemer et al., 1999). Much of the work on loyalty in this decade has used this conceptualization (Hallowell, 1996).

Furthermore, Gremier and Brown (1996) recognize that there is also a cognitive aspect to customer loyalty. The new concept of loyalty, which refers to service loyalty, then can be formulized as: "The degree to which a customer exhibits repeat purchasing behavior from a service provider, possesses a positive attitudinal disposition toward the provider, and considers using only this provider when a need for this 
service exists." (Gremier \& Brown, 1996). This is also reflected in the work of Zeithaml, Berry, \& Parasuraman (1996) in Bloemer et al., (1999) in measuring service loyalty. Kotler and Keller (2006: 135) identify that the substance of loyalty virtually is not different: "A deeply held commitment to-purchase or re-patronize a preferred product or service in the future despite situational influences and marketing efforts having the potential to cause switching behavior." This definition will be the one in use.

Measuring Loyalty. Wulf et al., (2001) determine the measurement of loyalty through two aspects i.e. recommendation to others and intensively purchasing. Whereas Getty and Thompson (1994) measure loyalty through the attitude dimension (positive reference to others, recommendation to others) and behavioral dimension (trust, re-purchase, and loyalty). The measurement of Wulf et al. will be in use.

The Relation between Brand Equity and Customer's Loyalty, also Product Leadership and Customer's Loyalty. Anything good concerning a product, included the superiority of the product, will obviously increase the customer's perception about the positive product attributes and favorable consequences of brand use (Peter \& Olson, 2002). It inevitably produces customer's satisfaction (Kotler, 2000). While satisfaction stimulates the customer to let their cognitive process be more favourable to the product, it subsequently encourages the customer to repeat their purchase and recommendation of the product to others. So, the following can be formulated,

H4: Brand equity influences a customer's loyalty

H5: Product leadership influences a customer's loyalty

\section{RESEARCH MODEL}

Refering to the theory and hypotheses, a research model can be withdrawn as follows (Figure 2),

\section{METHOD}

The sample is drawn through purposive sampling, particularly using the judgment technique (Cooper \& Schindler, 2008). Data were collected from questionnaires, distributed to respondents who still (or until recently) owned a Nokia mobile phone and have repeat purchased at least once. After being examined based on the data completion, 100 questionnaire forms were considered suitable for our study, out of 104 forms (a 96,15\% response rate), which meets the sample adequacy requirement (Ghozali, 2005; Hair et al., 1998) and liable to be further administered. A Likert scale is used, with a five-point scale ranging from 1 (= completely disagree) to 5 (= completely agree). The instrument, which is denoted to the indicators, will firstly be justified through confirmatory factor analysis. Further, data are analyzed by employing Amos 5.0.

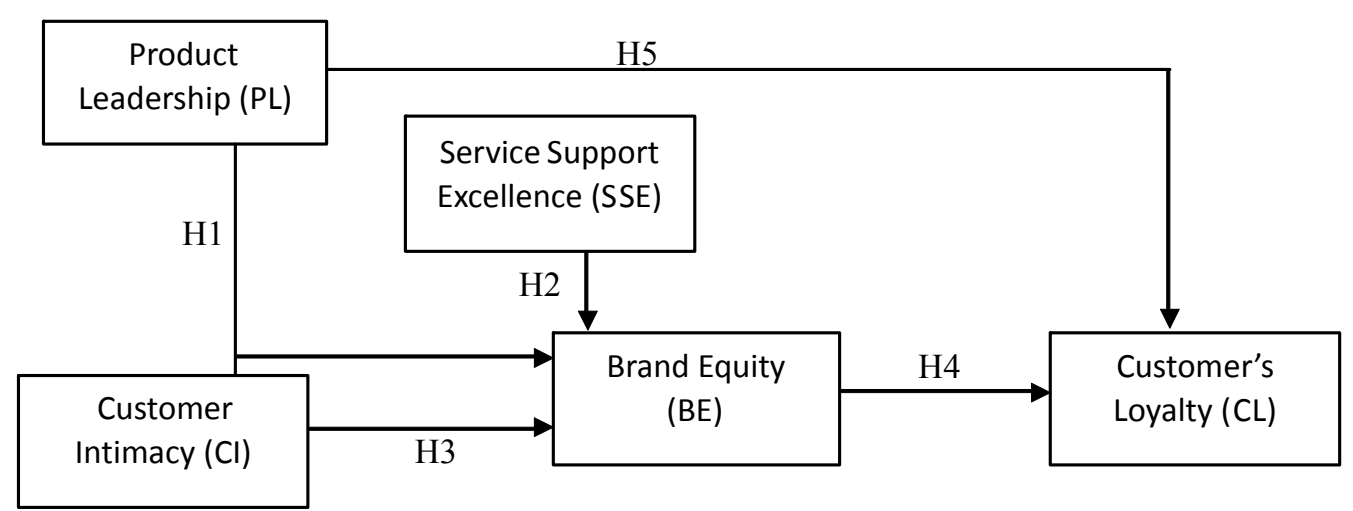

Figure 2. Research Model 


\section{Confirmatory Factor Analysis}

First Phase CFA. The confirmatory factor analysis was not simultaneously carried out, but carried out in phases. The first phase contained 3 independent variables, i.e. product leadership, service support excellence, and customer intimacy, which produced $\chi 2$, cmin/df, GFI, AGFI, and TLI score that are not in accordance with expected good indices. It does however indicate that there is no difference between covariance sample matrix and population covariance matrix estimated (Table 1).

The initial 1st CFA scores which do not meet good criteria, might be corrected. The modifi- cation indices produced by Amos output indicate that the scores might be better by connecting e 6 $\leftrightarrow \mathrm{e} 5$. As a result, the modification model yields better scores (Table 1, Figure 3).

Second Phase CFA. The 2nd phase CFA contains 2 variables, brand equity and customer's loyalty. It also comprises 2 stages. The first stage did not give the scores we expected, though some, such as chi-square and GFI, do fit (Table 2). This might be remedied by connecting e13 and e14. As a consequent, the second stage which denotes the modification model, produced scores that nearly all met the criteria (Table 2, Figure 4).

Table 1. First Phase Confirmatory Factor Analysis

\begin{tabular}{cccc}
\hline Indicators & 1st CFA & 2nd CFA & Threshold \\
\hline Chi-square/Prob & $99.555 / 0,000$ & $62,061 / 0,118$ & $32.909 / \mathrm{p}>0.05$ \\
Cmin/df & 1,952 & 1,241 & $<2$ \\
GFI & 0,841 & 0,906 & High \\
AGFI & 0,757 & 0,853 & $\geq 0,9$ \\
TLI & 0,812 & 0,952 & $\geq 0,9$ \\
RMSEA & 0,98 & 0,049 & 0,05 s.d 0,08 \\
\hline
\end{tabular}

Source: data analysis

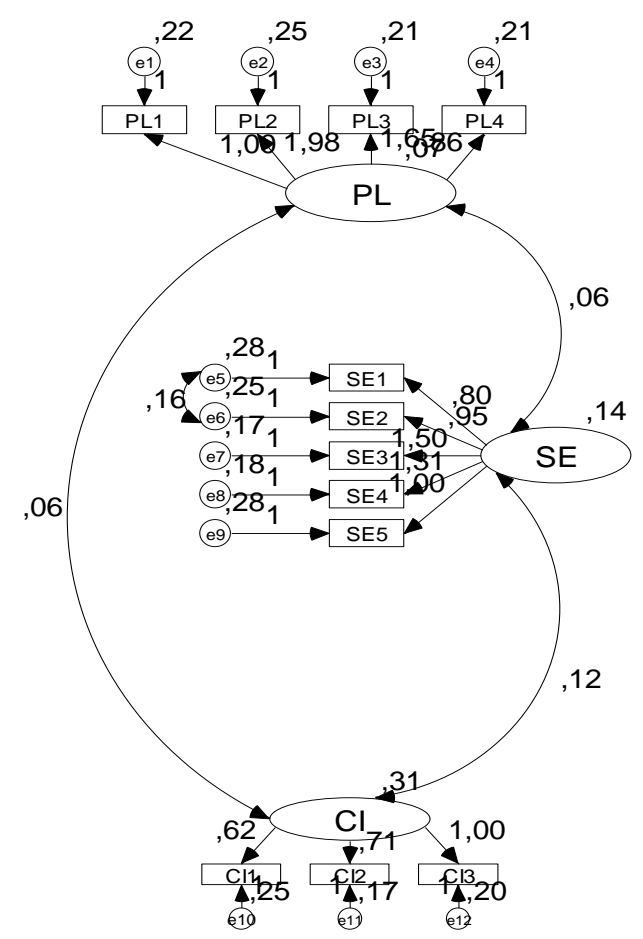

chi-square $=62,061$

prob $=, 118$

$\mathrm{cmin} / \mathrm{df}=1,241$

$\mathrm{GFI}=, 906$

AGFI $=, 853$

$\mathrm{TLI}=, 952$

RMSEA $=, 049$

Figure 3. Modification Model of the 1st Phase CFA 
Table 2. Second Phase Confirmatory Factor Analysis

\begin{tabular}{cccc}
\hline Indicators & 1st CFA & 2nd CFA & Threshold \\
\hline Chi-square/Prob & $17,363 / 0,027$ & $6,983 / 0,431$ & $22.458 / \mathrm{p}>0.05$ \\
Cmin/df & 2,170 & 0,998 & $<2$ \\
GFI & 0,940 & 0,977 & High \\
AGFI & 0,843 & 0,932 & $\geq 0,9$ \\
TLI & 0,895 & 1.000 & $\geq 0,9$ \\
RMSEA & 0,109 & 0,000 & 0,05 to 0,08 \\
\hline
\end{tabular}

Source: data analysis

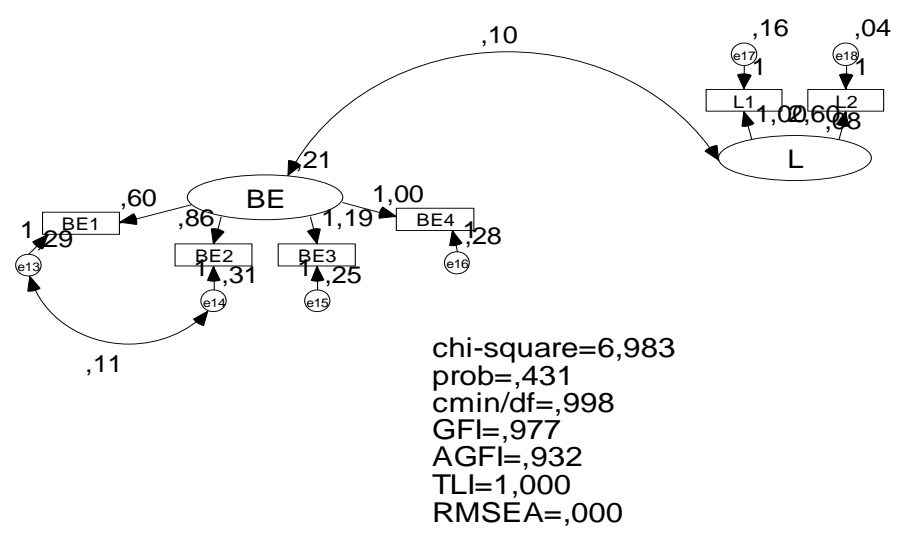

Figure 4.Modification Model of the 2nd Phase CFA

Standardized Regression Weight of Indicators. The modification model of both 1st and 2nd phase CFA produces a standardized regression weight for all indicators $>0,4$ which denotes that the factor loading of the manifests are above the minimum requirement (Ferdinand, 2002) (Table 3). It denotes that all indicators of PL (PL1, PL2, PL3, PL4), SE (SE1, SE2, SE3, SE4, SE5), CI (CI1, CI2, CI3), BE (BE1, BE2, $\mathrm{BE} 3, \mathrm{BE} 4)$ and $\mathrm{L}(\mathrm{L} 1, \mathrm{~L} 2)$ are valid.

\section{The Structural Equation Model}

This model has three independent variables and two dependent variables, of which the primary dependent variable, to some extent, is treated as the fourth independent variable. Since the purpose of the study is to know the relationship between the first three independent variables and the primary dependent variable, likewise the four independent variables (of which one was initially a dependent variable) and the second dependent variable, separately and simultaneously, a structural equation model was employed (Hair et al., 1995).
Table 3. Standardized Regression Weights:

\begin{tabular}{cccc}
\hline & & & Estimate \\
\hline PL1 & $<---$ & PL & 0,491 \\
PL2 & $<---$ & PL & 0,724 \\
PL3 & $<---$ & PL & 0,688 \\
PL4 & $<---$ & PL & 0,449 \\
SE5 & $<---$ & SE & 0,574 \\
SE4 & $<---$ & SE & 0,753 \\
SE3 & $<---$ & SE & 0,805 \\
SE2 & $<---$ & SE & 0,576 \\
SE1 & $<---$ & SE & 0,483 \\
CI3 & $<---$ & CI & 0,775 \\
CI2 & $<---$ & CI & 0,687 \\
CI1 & $<---$ & CI & 0,567 \\
BE3 & $<---$ & BE & 0,733 \\
BE2 & $<---$ & BE & 0,573 \\
L1 & $<---$ & L & 0,579 \\
L2 & $<---$ & L & 0,966 \\
BE1 & $<---$ & BE & 0,453 \\
BE4 & $<---$ & BE & 0,648 \\
\hline Sol
\end{tabular}

Source: Amos output 
An initial structural equation model was drawn by connecting all the variables as hypothesized. This model is likely not thoroughly appropriate to expectancy, eventhough 2 indicators, i.e. $\mathrm{cmin} / \mathrm{df}$ and RMSEA do already fit. Consequently, a modification model was generated by connecting e6 $\leftrightarrow \mathrm{e} 5$ and e $14 \leftrightarrow \mathrm{e} 13$. This modification model appears to produce better scores than before (Table 4, Figure 5).

Table 4 shows that not all indicators meet the criteria. However, the model apparently is a reasonable fit. Some indicators support the statement, i.e. the TLI's score $(0,947)$ is more than the limit $(0,9)$. Likewise, the Cmin/df's score $(1,205)$ surpass the cutoff point (less than 2 ), and RMSEA's score which is fewer than 0,08 . The model belongs with one that has an estimated covariance sample matrix and population covariance matrix which are similar.

\section{Evaluation of Assumptions}

Normality. Evaluation of normality was carried out by using a multivariate test (Ferdinand, 2002; Ghozali, 2008). It demonstrates normality if the kurtosis critical value is less than 2,58 . While the value is just 2,112 , the modified structural equation model meets the criterium.

Outliers. Evaluation of outliers was also carried out with a multivariate test (Ferdinand, 2002; Ghozali, 2008). The test firstly needed the chi-square value determining, which subsequently was used as the upper limit. It was calculated by searching a chi-square table whose degree of freedom is equal to the amount of variables employed, (18), under the degree of significance $(p)=0,001$. The chi-square value was determined to be 42,3124 . If all the scores of Mahalanobis distance are less than 42,3124, it could be inferred that there is no outlier.

Table 4. Indicators of the Modified SEM

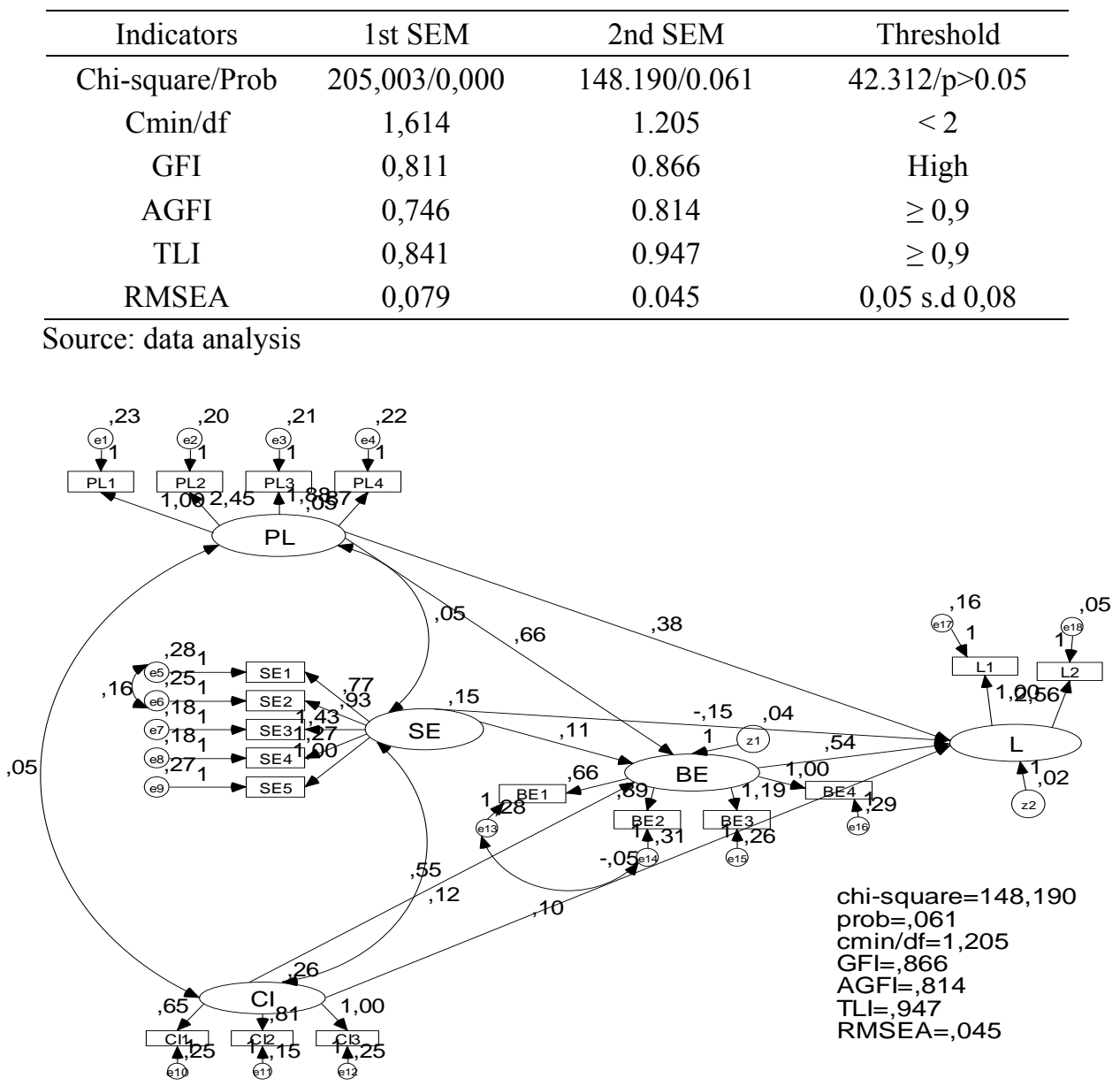

Figure 5. Modified Model of the Initial Structural Equation Model 
Multicollinearity and Singularity. According to the Amos output, the determinant of sample covariance matrix is equal to 2,567 . The value is more than zero. As a consequent, it belonges to no multicollinearity and singularity category.

\section{Reliability Measurement}

The reliability measurement employed here was the construct validity (Ghozali, 2008). The term reliability denotes: "A measure of the internal consistency of the construct indicators, depicting the degree to which they 'indicate' the common latent (unobserved) construct" (Hair et al., 1998: 641).

The structural equation modeling produced a construct reliability (CR) for each variable as follows: variable PL 0,68; variable SE 0,78; variable CI 0,70 ; variable $\mathrm{BE} 0,72$; and variable CL 0,75 (Table 5). The CR scores are appropriate since they are more than 0.70 (Ghozali, 2008), except PL's CR that is a little lesser than 0,70 (Table 5).

\section{Test of Hypotheses}

The regression weights output indicates that the influence of PL to BE is significant $(p=$ $0,033)$. Likewise, the influence of CI to $B E(p=$ $0,001)$. Conversely, the influence of SE to $\mathrm{BE}$ is not significant $(p=0,574)$. It means that there is support for hypothesis 1 as well as hypothesis 3 . Unfortunately, there is no support for hypothesis 2.

Table 5. Construct Reliability and Variance Extracted

\begin{tabular}{cccc}
\hline \multirow{2}{*}{ Construct } & \multicolumn{3}{c}{ Construct Reliability } \\
\cline { 2 - 4 } & Value & Cut-off & Title \\
\hline PL & 0.68 & 0.70 & Marginal \\
SE & 0.78 & 0.70 & Reliable \\
CI & 0.70 & 0.70 & Reliable \\
BE & 0.72 & 0.70 & Reliable \\
L & 0.75 & 0.70 & Reliable \\
\hline
\end{tabular}

Source: data analysis

The influence of BE to $\mathrm{L}$ is also significant $(p=0,022)$. In other words, there is also support for hypothesis 4 . In contrast $\mathrm{H} 5$ is not supported since its probability $(\mathrm{p}=0,221)$ is over 0,05 .

Table 6. Regression Weights: (Group number 1 - Default model)

\begin{tabular}{cccccccc}
\hline & & & Estimate & S.E. & C.R. & P & Label \\
\hline L & $<---$ & PL &, 377 &, 308 & 1,224 &, 221 & par_13 \\
BE & $<---$ & SE &, 113 &, 201 &, 563 &, 574 & par_14 \\
BE & $<---$ & CI &, 549 &, 171 & 3,212 &, 001 & par_16 \\
BE & $<---$ & PL &, 660 &, 310 & 2,127 &, 033 & par_24 \\
L & $<---$ & BE &, 536 &, 247 & 2,546 &, 022 & par_15 \\
PL1 & $<---$ & PL & 1,000 & & & & \\
PL2 & $<---$ & PL & 2,450 &, 675 & 3,631 & $* * *$ & par_1 \\
PL3 & $<---$ & PL & 1,875 &, 517 & 3,625 & $* * *$ & par_2 \\
PL4 & $<---$ & PL &, 872 &, 301 & 2,893 &, 004 & par_3 \\
SE5 & $<---$ & SE & 1,000 & & & & \\
SE4 & $<---$ & SE & 1,271 &, 237 & 5,365 & $* * *$ & par_4 \\
SE3 & $<---$ & SE & 1,426 &, 277 & 5,153 & $* * *$ & par_5 \\
SE2 & $<---$ & SE &, 931 &, 213 & 4,378 & $* * *$ & par_6 \\
SE1 & $<---$ & SE &, 771 &, 203 & 3,807 & $* * *$ & par_7 \\
BE3 & $<---$ & BE & 1,185 &, 202 & 5,862 & $* * *$ & par_8 \\
BE2 & $<---$ & BE &, 892 &, 186 & 4,803 & $* * *$ & par_9 \\
C13 & $<---$ & CI & 1,000 & & & & \\
CI2 & $<---$ & CI &, 812 &, 139 & 5,857 & $* * *$ & par_10 \\
C11 & $<---$ & CI &, 655 &, 136 & 4,823 & $* * *$ & par_11 \\
L1 & $<---$ & L & 1,000 & & & & \\
L2 & $<---$ & L & 2,565 &, 493 & 5,203 & $* * *$ & par_12 \\
BE1 & $<---$ & BE &, 660 &, 167 & 3,959 & $* * *$ & par_19 \\
BE4 & $<---$ & BE & 1,000 & & & & \\
\hline
\end{tabular}

Source: Amos output 


\section{CONCLUSION AND DISCUSSION}

The findings indicate that not all hypotheses are empirically supported. The relationships of service support excellence to brand equity and product leadership to customer's loyalty are minor. However, the relationship between product leadership and customer intimacy to brand equity are significant. Likewise the influence of brand equity to customer's loyalty.

The insignicant influence of sales support excellence to brand equity might be illustrated as follows, first of all, sales support excellence is common along with the product itself. It should be brought together with the product. Agilier (2014) says that: "There is no point being a product leader if the customer service is lousy." Secondly, in the customers' perception the most important thing is the superiority of the product itself, they seemingly ignore the service, since a superior product should provide quality and durability.

An explanation for the lack of support for the relationship between product leadership and customer's loyalty might be found in the research of Santosa (2008), Szymanski \& Henard (2001), and Mittal \& Lassar (1998), who identified that a customer's loyalty is conveniently predicted by satisfaction. Therefore, a new study should be designed which involves satisfaction as an antecedent of customer's loyalty.

Referring to the question in the title of this paper, 'Can product leadership be a predictor of customer's loyalty?', the answer is clearly that the product leadership cannot directly predict the customer's loyalty. It affects customer's loyalty indirectly through the brand equity.

\section{Implication}

The result of the study highlights the important role of the brand equity. The strategic position of brand equity is in truth critical. It apparently encourages consumers to confidently make a decision to purchase. A product whose brand equity is high undoubtedly generates a high sales volume. In addition, customers who purchase the product are likely to be proud to own it. Furthermore, anything relating to the brand will obviously make them consider it. Moreover, the brand equity significantly has an effect on re-purchase and customers' behavior in giving a reccommendation about the brand to others. As a result, the brand equity is inevitably a key to it's marketing success.

This study finds that the power of brand equity is able to be ignited by a product leadership strategy and an intimate customer strategy. It is suggested that firms may employ the product leadership strategy only, or the customer intimacy strategy only, or both. Since the product leader will shape the product to match customers' needs, it is recommended to pursuit both. In other words, an innovation which is inspired by product leadership should preferably meet the individual customer's needs. This combination generates a model for both product leadership and customer intimacy having a good effect on developing a brand equity.

\section{Limitation of the Study}

The study is actually inspired by Kalypso's suggestion (http: kalypso.com, capabilities, services, product-leadership-transformation) that the product leadership is prominent in today's highly competitive market place. However, the concepts of product leadership and support service excellence do not actually produce a new paradigm. Furthermore, in this study the model is supposedly accurate, ignoring other variables which are probably in the right position in undestanding the effects of product leadership.

\section{Suggestion for Further Research}

Since the model of the study is just one of many interpretations which can be developed, it is suggested to that further models be built which can elaborate other possibilities for showing the effect of product leadership in the highly competitive market place.

\section{REFERENCES}

Agilier, 2014. "Discipline of the Market Makers" by Michael Treacy and Fred Wiersema. Available at: http://www.agilier. $\mathrm{com} /$ book-reviews/discipline-of-the-marketmakers.html. accessed at May 8, 2014. 
Assael, H, 1995. Consumer Behavior \& Marketing Action. Cincinnati, Ohio: SouthWestern College Publishing.

Bloemer, Josee, Ko de Ruyter, and Martin Wetzels, 1999. "Linking Perceived Service Quality and Service Quality: A Multidimensional Perspective". European Journal of Marketing, 38 (12), 1082-1106.

Carnana, A, 2002. "Service Loyalty: The Effects of Service Quality and the mediating role of Customer Satisfaction". European Journal of Marketing, 36 (7/8), 811-828.

Cooper, D.R, and P.S. Schindler, 2001. Business Research Methods, $7^{\text {th }}$ edition. Boston: McGraw-Hill/Irwin.

Cravens, D.W, 2000. Strategic Marketing, $6^{\text {th }}$ ed. Boston: Irwin-McGraw-Hill.

Cunningham, R.M, 1956. "Brand Loyalty: What, Where, How Much". Harvard Business Review (39), 116-138.

Dick, A.S, and K. Basu, 1994. "Customer Loyalty: Toward an Integrated Conceptual Framework". Journal of the Academy of Marketing Science, (22), 99-113.

Ferdinand, A, 2002. Structural Equation Modeling Dalam Penelitian Manajemen. Semarang: BP Undip.

Ghozali, I, 2005. Model Persamaan Struktural: Konsep dan Aplikasi dengan Program Amos Ver 5.0. Semarang: BP Undip.

Gremler, D.D, and S.W. Brown, 1996. "Service Loyalty; Its Nature, Importance, and Implications" in Edvardsson B, et al, Advancing Service Quality: A Global Perspective. NY: ISQA.

Hallowell, R, 1996. "The Relationships of Customer Satisfaction, Customer Loyalty, and Profitability: An Empirical Study. International Journal of Service Industry Management, 7 (4), 27-42.

Hair, et al, 1998. Multivariate Data Analysis. New Jersey: Prentice Hall.

Hopkin, M.R, 2011a. Product-leadership. Available at: http: leadonpurposeblog.com accessed January 24, 2011.

Hopkin, M.R., 2011b. Five-rules-for-executiveproduct-leadership. Available at: http: leadonpurposeblog.com accessed July 9, 2011.
Jacoby, J and R.W. Chestnut, 1978. Brand Loyalty: Measurement and Management. New York: John Wiley.

Kalypso, year not available. Capabilities, Services, Product-leadership, Transformation. Available at: http: kalypso.com, capabilities, services, product-leadership-transformation accessed at May 22, 2011.

Kostecki, M.M,1994. Marketing Strategies for Services: Globalisation, Client Orientation, Deregulation. Oxford: Pergamon Press.

Kotler, P, and G. Armstrong, 2000. PrinsipPrinsip Pemasaran, 8th ed. Interpreted by Damos Sihombing and Wisnu Candra Kristiaji. Jakarta: Penerbit Erlangga.

Kotler, P, and K.L. Keller, 2006. Marketing Management, $12^{\text {th }}$ ed. Upper Saddle River, New Jersey: Pearson Education Inc.

Kotler, P, 2000. Marketing Management, the Millenium Edition. Upper Saddle River, New Jersey: Prentice-Hall Inc.

Liljander, V and T. Strandvik, 1995. "The Nature of Customer Relationships in Services." Advances in Service Management, (4), 141167.

Mars, 2013. Competitive Strategies in Operational Excellence, Customer Intimacy and Product Leadership. Available at: http:// www.marsdd.com/mars-library/competitivestrategies-in-operational-excellencecustomer-intimacy-and-product-leadership, accessed at May 8, 2014.

MISC, 2014. In Pursuit of Customer Intimacy and Operational Excellence. Available at: http://www.miscmagazine.com/in-pursuitof-customer-intimacy-and-operationalexcellence/ accessed at May 8, 2014. '

Mittal, B and WM. Lassar, 1998. "Why do Customer Switch? The Dynamics of Satisfaction versus Loyalty." The Journal of Services Marketing. 12 (3), 177-194.

Nokia, inc., year not available. Available at: http: en.wikipedia.org, wiki, Nokia accessed at May 22, 2011.

Nokia, inc., year not available. Available at: http:gadnix.com, 2009/04/market-shareponsel-di-indonesia accessed at May 22, 2011. 
Nokia, inc., year not available. Available at: www. imglanding? $\mathrm{q}=$ market $\% 20$ share $\%$ 20nokia\&imgurl accessed at May 22, 2011.

Nokia, inc., year not available. Available at: http: old.forumponsel.com, forum, showflatNumber-182727-page-0-sb-5-fpart-1.html accessed at May 22, 2011.

Nokia, inc., year not available. Available at: www.nokia.com accessed at May 22, 2011.

Oliver, R. L, 1997. Satisfaction: A Behavioral Perspective on Consumers. Meidenhead: McGraw-Hill

Peter, J.P, and J.C. Olson, 2002. Consumer Behavior and Marketing Strategy, $6^{\text {th }}$ ed. Boston: Irwin McGraw-Hill.

Santosa, E, 2008. "Investigating Drivers of Customer Loyalty: Is Directly Affected by Service Quality and Image or Indirectly Through Satisfaction? The Case of People's
Credit Bank (BPR)." Jurnal Ekonomi dan Bisnis, Volume XIV (1), 15-32.

Schiffman, L.G, and L.L. Kanuk, 2000. Consumer Behavior, $7^{\text {th }}$ ed. Upper Saddle River, New Jersey: Prentice-Hall Inc.

Szymanski, DM. and DH. Henard, 2001. "Customer Satisfaction: A Meta Analysis of the Empirical Evidence." Journal of the Academy of Marketing Science. 29. (1). 16-35

Thompson, A.A, et al., 2010. Crafting and Executing Strategy: The Quest for Competitive Advantage, 17th ed. Boston: McGraw-Hill Irwin.

Treacy, M and F. Wiersma, 1997. The Discipline of Market Leaders: Choose Your Customers, Narrow Your Focus, Dominate Your Market. Massachusetts: Addison-Wesley

Zeithaml, V.A, and M.J. Bitner, 2003. Services Marketing, $3^{\text {rd }}$ ed. New York: McGraw-Hill Co. 